\title{
Bioactive components and the effect of aqueous leaf extract of Maesobotrya barteri (Baill.) Hutch. (Euphorbiaceae) on haematological profile in paracetamol-induced Wistar rats
}

\section{U. Ogunka-Nnoka* and B. W. Abbey}

Department of Biochemistry. University of Port Harcourt. Choba. Rivers State. Nigeria.*Email: cogunkannoka@yahoo.co.uk.

\begin{abstract}
The study evaluates the bioactive components and the effect of aqueous leaf extract of Maesobotrya barteri (Baill.) Hutch. (Euphorbiaceae) on the haematological profile of paracetamol-induced Wistar albino rats. Standard methods were used in the proximate, phytochemical and haematological profile analysis. The results of the proximate composition revealed high values for crude fiber (49.13\%), carbohydrates $(16.33 \%)$ and protein $(10.94 \%)$. Phytochemical studies showed the presence of alkaloids, flavonoids, saponins, phenols and tannins within the concentration range of $0.0003-94.68 \mu \mathrm{g} / \mathrm{mL}$. Twenty-four hours after the last oral administration, the rats were sacrificed. Blood was obtained by cardiac puncture. Results of the haematological profile at different dose levels $(200 \mathrm{mg} / \mathrm{kg}$, $300 \mathrm{mg} / \mathrm{kg}$ and $500 \mathrm{mg} / \mathrm{kg}$ body weight) did not show any significant difference $(p>0.05)$ when compared with the control. A slight increase was observed in the erythrocytes (red blood cells, haemoglobin, packed cell volume and platelets). Meanwhile, a significant increase ( $p \leq 0.05)$ was observed in the WBC and platelets of the groups induced with paracetamol only. However, administration of ascorbic and the sample extract reduced the white blood cells and platelet levels. The study revealed that $M$. barteri leaves contain an appreciable amount of nutrients, bioactive constituents and may serve as a blood booster.
\end{abstract}

Keyword: Bioactive components; Maesobotrya barteri; Haematological profile; Paracetamol; Wistar rats.

\section{Introduction}

Plants provide food, medicine, fuel, clothing and shelter. About $30 \%$ to $40 \%$ of today's conventional drugs used in the medicinal and curative properties are employed in herbal supplements, botanicals, nutraceuticals and drugs (Essiette and Obiobohu, 2014).
Received

July 29, 2019

Accepted

December 11, 2019

Released

December 31, 2019

Full Text Article

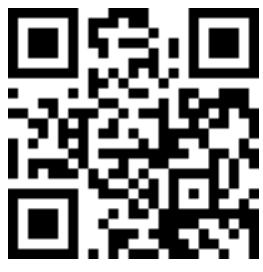

ORCID

D 0000-0002-6232-5287 C. U. Ogunka-Nnoka

(ㄱ) 0000-0002-2829-0439 B. W. Abbey 
nutrients (Kitamura et al., 2012). Studies have shown that consumption of many different wild plants as food provides nutritional benefits (Cook et al., 2000, Vanderjagt et al., 2000). Medicinal and aromatic plants contain bioactive compounds (phytochemicals) which inhibits the activities of bacteria and other microorganisms (Okwu and Ekeke, 2003). These bioactive chemical substances include flavonoids, saponins, anthocyanin, tannins etc which confers on the plants the medicinal properties from which important drugs could be prepared. Phytochemicals also known as secondary metabolites are formed during
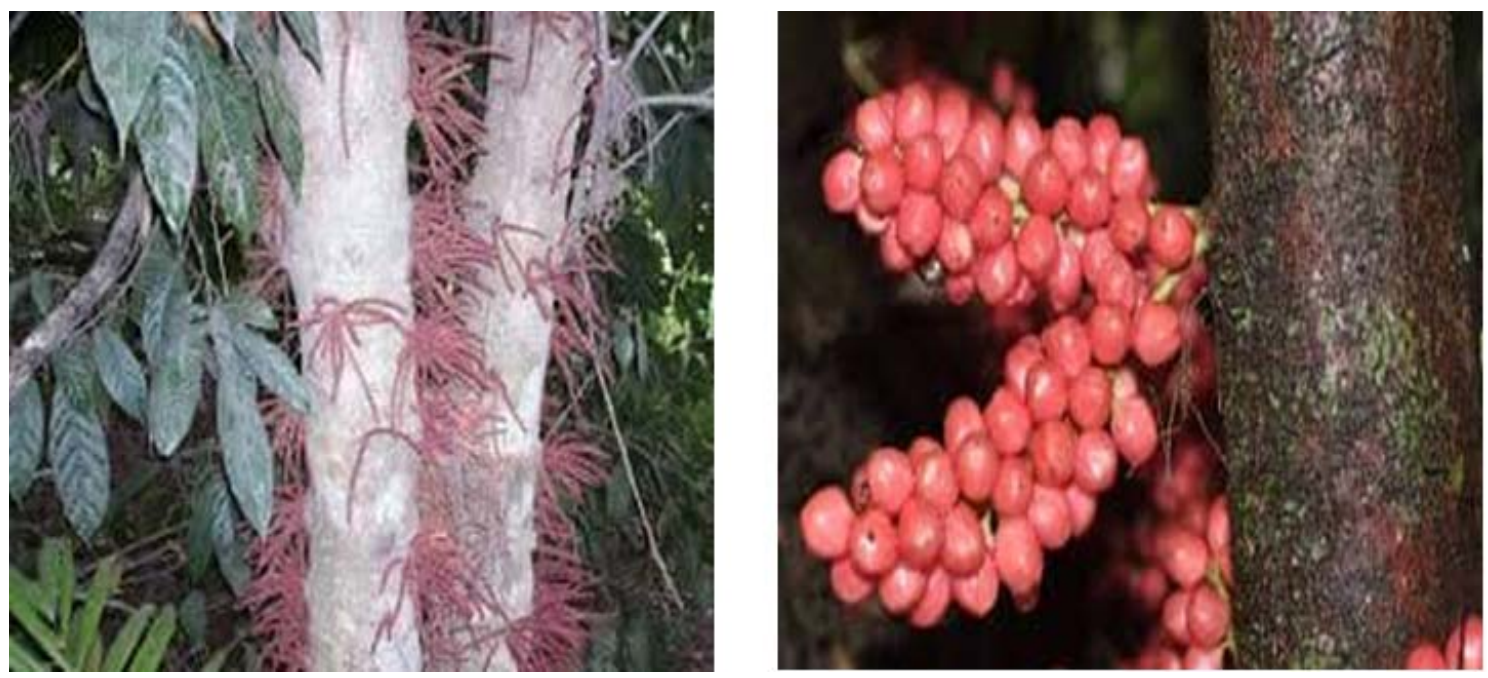

the normal metabolic processes in plants (Izevbigie et al., 2004). Generally, as with many plants, Maesobotrya bateri (Figure 1 ) is considered as a food with medicinal effects (Ogle et al., 2003). The plant Maesobotorya barteri is of the Euphorbiaceae Family; a rain forest plant that bears, fruit from April to June. It is the most widely distributed Maesobotrya species in Nigeria. The fruits are edible and succulent different parts of the plant have been in use at the local level in the treatment of dysentery, diarrhoea, jaundice, urethral discharge etc. (Dalziel, 1948).

Figure 1. Maesobotrya bateri leaves, stem and fruits.

Plant components such as leaves and stems have been reported to have protective effects on toxicity of some drugs. Paracetamol (acetaminophen) is used widely as an analgesic and antipyretic (Aghababian, 2010). It is safe if taken at recommended doses; while a small overdose could be detrimental to health. Remack and Mathew (1975) reported that between $24 \mathrm{~h}$ and $72 \mathrm{~h}$ of paracetamol overdose, signs of elevated liver damage may occur. Oboh and Ekperigin (2004) reported that liver toxicity has been associated with haemolytic anaemia. Testing of haematological indices can be used to determine the extent of the deleterious effect of foreign compounds including plant extract on the blood composition of animals. The present study was undertaken to identify some nutrients, bioactive agents present in the leaves of Maesobotorya barteri as well as the effect of aqueous leaf extract of this plant on haematological profile in paracetamolinduced Wistar rats. 


\section{Materials and methods}

\section{Plant material collection and preparation \\ Maesobotorya barteri leaves were} collected from a farmland in Rumuodomaya Village in Obio/Akpor Local Government Area of Rivers State, Nigeria. The plant was authenticated by Dr. Edwin Nwosu of the Department of Plant Science and Biotechnology, University of Port Harcourt, Rivers State, Nigeria. The leaves were properly sorted and air-dried at room temperature $\left(25^{\circ} \mathrm{C}\right.$ $-27^{\circ} \mathrm{C}$ ) for $72 \mathrm{~h}$ to a constant weight. The dried leaves were ground and sieved to a fine powder. The sieved sample was stored in an airtight sample container until further analysis.

\section{Plant sample extraction}

The sample was weighed (84.7 g) into a conical flask and extracted with 2.5 $\mathrm{mL}$ distilled water with constant agitation for $10 \mathrm{~min}$ and left to stand for $24 \mathrm{~h}$. The sample was filtered using what man No. 1 filter paper. The filtrate was concentrated using rotary evaporator at $50{ }^{\circ} \mathrm{C}$ and dried in an evaporating dish placed on a boiling water bath.

\section{mination}

Proximate composition deter-

The proximate composition of the sample was determined using the standard methods of Analysis of Association of Officials Analytical Chemists (AOAC, 1995). The moisture content of the sample was determined by heating in an oven method at $105^{\circ} \mathrm{C}$. The crude protein was determined using micro-Kjeldahl Method. Crude lipid was determined by Soxhlet extraction methods using petroleum ester as extracting solvent. The ash content was determined using a muffle furnace set at $550{ }^{\circ} \mathrm{C}$ for $4 \mathrm{~h}$ until a constant weigh of ash was obtained. Crude fibre was determined using the method by SauraCalixto et al. (1983), while carbohydrate content was obtained by difference.

\section{Phytochemical analysis}

The powdered leaves of $M$. bateri were subjected to various sample preparation stages using standard laboratory procedures for determination of phytochemicals. GC-FID analysis of phytochemical constituents was according to the method described by Nwiloh et al. (2016) with slight modification. For the GC-FID analysis, the dried sample of $M$. bateri leaves ( $2 \mathrm{~g}$ ) was weighed and transferred into a test tube. $15 \mathrm{~mL}$ of ethanol and $10 \mathrm{~mL}$ of $50 \% \mathrm{w} / \mathrm{v}$ potassium hydroxide were added to the crushed root bark in the test tube. The test tube was allowed to stand in a water bath at $60{ }^{\circ} \mathrm{C}$ for $60 \mathrm{~min}$. Then the content of the test tube was carefully transferred into a separatory funnel and the tube rinsed into the same funnel with $10 \mathrm{~mL}$ of cold water, $10 \mathrm{~mL}$ of hot water, $20 \mathrm{~mL}$ of ethanol and $3 \mathrm{~mL}$ of hexane. The extract in the test tube was washed three times with $10 \mathrm{~mL}$ of $10 \% \mathrm{v} / \mathrm{v}$ ethanol solution. The extract solution was then dried with anhydrous sodium sulphate and the solvent was evaporated. A sample of the extract was made soluble in $100 \mu \mathrm{L}$ of pyridine of which $20 \mu \mathrm{L}$ was transferred into a vial on the gas chromatography machine for phytochemical analysis. The GC-FID phytochemical analysis was performed on a BUCK M910 Gas Chromatograph (GC) (BUCK Scientific, USA), equipped with a flame ionization detector (FID). A RESTEK 15 meter MXT-1 column (15 m x $250 \mu \mathrm{m} \times 0.15 \mu \mathrm{m})$ was used. The injector temperature was $280{ }^{\circ} \mathrm{C}$ with a split less injection of $2 \mu \mathrm{L}$ of sample and a linear velocity of $30 \mathrm{~cm}^{-1}$, Helium $5.0 \mathrm{~Pa}$ was the carrier gas with a flow rate of 40 m.min ${ }^{-1}$. The oven operated initially at $200{ }^{\circ} \mathrm{C}$, it was heated to $330{ }^{\circ} \mathrm{C}$ at a rate of $3{ }^{\circ} \mathrm{C} \mathrm{min}^{-1}$ and was kept at the temperature of $320{ }^{\circ} \mathrm{C}$. Phytochemicals were determined by the ratio between the area and mass of internal standard and the area of the identified phytochemicals. 


\section{Experimental animal design and extract administration}

Wistar albino rats (30) of both sexes weighing between 100-200 g were obtained from the animal house of the Department of Biochemistry, University of Port Harcourt, Rivers State was used in this study. The rats were housed in six cages of five each and were allowed to acclimatize for 10 days before the commencement of the experiment. Standard laboratory condition of $12 \mathrm{~h}$ light and dark sequence at an ambient temperature of $25{ }^{\circ} \mathrm{C} \pm 2{ }^{\circ} \mathrm{C}$ and $35 \%$ $60 \%$ humidity were maintained. They were fed with standard diet produced by Top Feed Nigeria Limited and water ad libitium. Ethical guidelines and procedures for handling experimental animals were followed.

The extract was reconstituted in distilled water to give the required dose to the experimental rats which are distributed into six groups of five rats each.

- Group 1: Served as normal control, received normal diet and water

- Group 2: Served as the negative control, received $750 \mathrm{mg} / \mathrm{kg}$ bw (body weight) of paracetamol single does every $72 \mathrm{~h}$ for 10 days.

- Group 3: Served as the positive control, received $750 \mathrm{mg} / \mathrm{kg}$ bw of paracetamol single does every $72 \mathrm{~h}$ and $100 \mathrm{~g} / \mathrm{kg}$ bw of ascorbic acid (standard drug) was preadministered for 10 days.

- Group 4: Served as the test group rats were pre-treated with 200 $\mathrm{mg} / \mathrm{kg}$ bw of Measobotrya barteri extract for 10 days and $750 \mathrm{mg} / \mathrm{kg}$ bw of paracetamol once every $72 \mathrm{~h}$.

- Group 5: Served as the test group rats were pre-treated with 300 $\mathrm{mg} / \mathrm{kg}$ bw of Measobotorya barteri extract for 10 days and $750 \mathrm{mg} / \mathrm{kg}$ bw of paracetamol once every $72 \mathrm{~h}$.

- Group 6: Served as the test group rats were pre-treated with 500 $\mathrm{mg} / \mathrm{kg}$ bw of Measobotrya barteri extract for 10 days and $750 \mathrm{mg} / \mathrm{kg}$ bw of paracetamol once every $72 \mathrm{~h}$.

\section{Collection of blood sample}

After $24 \mathrm{~h}$ of the last dose, animals were anaesthetized in chloroform vapour (Mao et al., 2014) blood sample was collected by direct puncture into appropriately labelled heparinised bottles for haematological studies.

\section{Haematological evaluation}

Haematological tests for packed cell volume (PCV), haemoglobin (HB). Red blood cell (RBC) counts, white blood cell (WBC) count, platelet (PL) counts, neutrophil and lymphocytes counts were analysed according to the conventional methods reported by Aning et al. (1998).

\section{Statistical analysis}

Results were expressed as mean \pm standard error (S.E). One-way analysis of variance (ANOVA) test was first carried out to test for any differences between mean groups. If the difference between groups were established, the values of the treated groups were compared with those of control by a multiple comparison t-test. A value of $\mathrm{p}<0.05$ was interpreted as statistically significant

\section{Results and discussion}

\section{Proximate composition of Maesobotrya barteri leaves}

The proximate composition of leaves of Maesobotrya barteri is summarized in Table 1 . The results showed that the leaves contained $10.30 \%$ moisture, $11.50 \%$ ash, $10.94 \%$ crude protein, $1.80 \%$ crude fat, $49.13 \%$ crude fiber and $16.33 \%$ carbohydrate.

Table 1. Proximate composition of leaves of Maesobotrya barteri plant.

\begin{tabular}{lc}
\hline Components & \% Composition \\
\hline Moisture content & $10.30 \pm 0.03$ \\
Ash & $11.50 \pm 0.01$ \\
Protein & $10.94 \pm 0.00$ \\
Fat & $1.80 \pm 0.06$ \\
Crude fibre & $49.13 \pm 0.00$ \\
Carbohydrate & $16.33 \pm 0.00$ \\
\hline
\end{tabular}

Values are mean \pm SD. 
The crude fibre which had the highest value has the ability to reduce cholesterol level in the serum and prevent diseases (Rao and Newark, 1998; Ishida et al., 2000). Also, the high crude fiber, makes the leaves a favourable forage since high fiber content food helps in digestion and the prevention of colon cancer. Non-starchy plant materials are the richest source of dietary fiber and are helpful in the treatment of obesity, gastrointestinal disorders and diabetes (Agostoni et al., 1995). The level of moisture present in this sample showed that the leaves are not prone to fast deterioration since food with high moisture content are prone to spoilage (Fennema and Tannenbaum, 1996). The high ash content showed a reflection of the mineral content in leave sample. The content of crude fat obtained showed that the leaves are more palatable because dietary fat function to increase food palatability by absorbing and retaining flavours (Ilodibia et al., 2014). Protein is an essential plant molecule containing nitrogen in food samples. The value of protein reported here indicated that it is a rich source of protein and can contribute to the formation of hormones which controls a variety of body functions such as growth, repairs and maintenance of tissue (Mau et al., 1999). Our study, corroborate the report of Essiett and Obioboho (2014); they reported crude protein and crude fat levels of $10.80 \%$ and $2.1 \%$ respectively for Ipomoea triloba. The amount of carbohydrate $(16.33 \%)$ disagrees with the carbohydrate content of $53.67 \%$ for Tribulus terrestris leaves as reported by Asibey-Berko and Tayle (1999).

\section{Phytochemical constituents}

Results of phytochemical analysis

(Table 2) of aqueous extract of Maesobotrya barteri leaves showed that alkaloids $\quad(0.003 \mu \mathrm{g} / \mathrm{mL}), \quad$ oxalates (0.2003 $\mu \mathrm{g} / \mathrm{mL})$, flavonoids $(0.1110$ $4.4281 \mu \mathrm{g} / \mathrm{mL})$, phenols $(94.6833$ $\mu \mathrm{g} / \mathrm{mL})$, tannins (91.2385 $\mu \mathrm{g} / \mathrm{mL}$ ) and saponin $(0.4417 \mu \mathrm{g} / \mathrm{mL})$ were present.
Table 2. Phytochemical constituents of leaves of Maesobotrya barteri plant.

\begin{tabular}{lc}
\hline Phytochemical & $\begin{array}{c}\text { Concentration } \\
(\boldsymbol{\mu g} / \mathbf{m L})\end{array}$ \\
\hline Alkaloid & \\
$\quad$ Spartein & 0.0003 \\
Oxalate & 0.2003 \\
Flavonoid & \\
$\quad$ Anthrocyanin & 4.4281 \\
$\quad$ Catechin & 0.1110 \\
Phenol & 94.6833 \\
Tannin & 91.2385 \\
Saponnin & \\
$\quad$ Sapogenin & 0.4417 \\
\hline Total & $\mathbf{2 0 2 . 6 9 9 5}$ \\
\hline
\end{tabular}

The results revealed that phenol content $(94.33 \mu \mathrm{g} / \mathrm{mL})$ and tannin $(91.2385 \mu \mathrm{g} / \mathrm{mL})$ were higher than the other photochemical components (Figure $2)$. The phytochemical present in the plant may have contributed to the medicinal value and physiological activity of the leaves (Soforowa, 1993). Phenolic compounds possess important pharmacological values, some having anti-inflammatory properties (Bruneton, 1995). The amount of alkaloids in the leaves of $M$. barteri may suggest its ability to stop disease (Gupta, 1994). Alkaloids have bactericidal and antispasmodic effects and can be used in the manufacture of sedatives. The level of saponin reported showed that the leaves can lower cholesterol level and act as an immune booster (Sadipo et al., 2000). In plants, saponin may serve to protect the plant against microbes and fungi as well as to enhance nutrient absorption and aid in animal digestion. The presence of saponin is well reported in plants where they serve as expectorants and emulsifying agents. Saponins are glycosides with distinctive foaming characteristics, and like phenols have anti-inflammatory properties (Akundu, 1984; Edeoga et al., 2006; Belewu et al., 2009). 


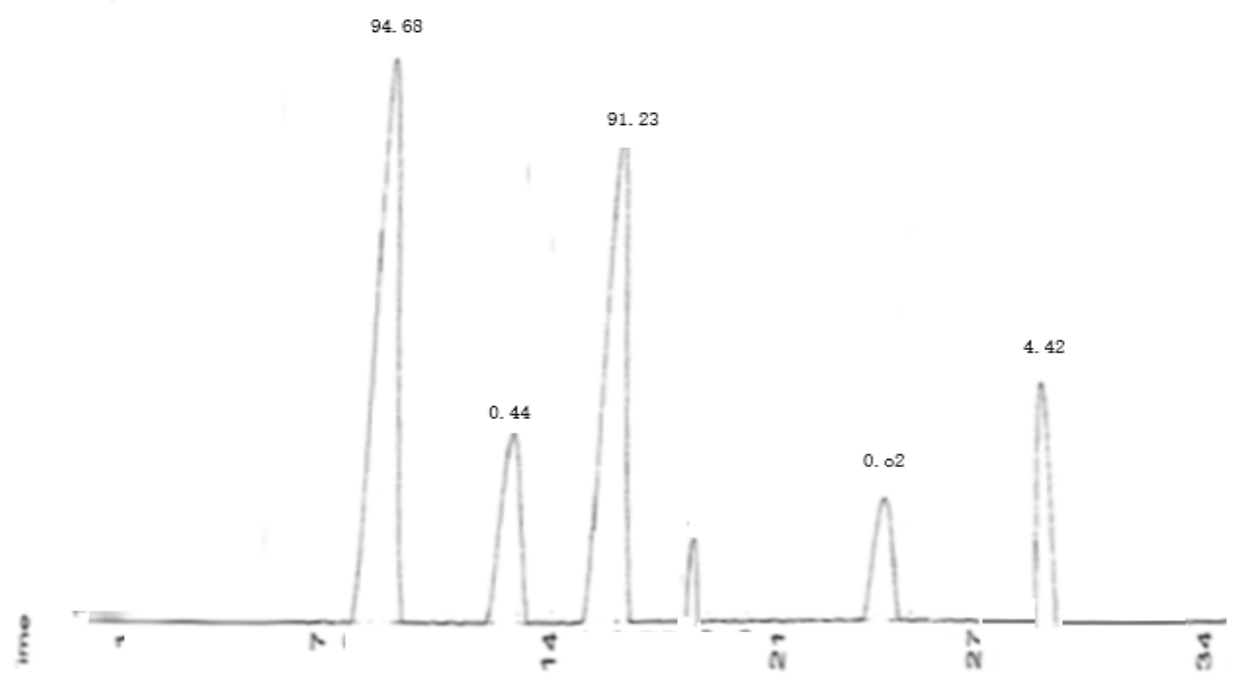

Figure 2. Chromatogram of phytochemical composition of M. bateri.

The anti-inflammatory activities of some saponin derivatives such as triterpenoids have been reported (Sahu and Mahato, 1994). According to Sparg et al. (2004), many saponins extracted from plant sources produce inhibition of inflammation in the mouse carrageenininduced oedema assay. Also, Okwu (2004), reported on the use of saponin in the manufacture of insecticides, drugs and synthesis of steroid hormones. $M$. Barteri sample had high content of tannins; tannins are known to have antiviral, antifungal, antibacterial, and antitumour properties (Andzouana and Monbouli, 2012); hence the presence of tannin in $M$. barteri strongly supports their use in wound treatments and tumours. Tannins have oxidation inhibiting activity and confer good flavour on leaves Nwauzoma and Dawari (2013). Our results corroborate the report by Etukudo and Osim, (2018). The presence of flavonoids is an indication that the leaves have high antioxidant, anti-tumor and inflammatory activities (Farquar, 1996; Okwu, 2004). The presence of these phytochemicals is a clear indication of its pharmacological relevance.

\section{Haematological profile}

Results of haematological profile (Figure 3-9) revealed that groups 3-6 showed slight elevation in the concentration of PCV, HB, and RBC as compared to groups 1 and 2; while WBC and platelet significantly $(\mathrm{p}<0.05)$ increased in negative control group. The assessment of the haematological parameters in Wistar rats is a valuable tool for monitoring the effect of plant extract on animal blood chemistry. Inducing paracetamol did not show any significant difference in the packed cell volume (PCV), haemoglobin (HB) and red blood cells (RBC) when compared to the control (group 1) as shown in Figures 35. Also, an elevated platelets count (Figure 6) in the paracetamol group was significant $(\mathrm{p}<0.05)$ compared with the control. The different dose levels of the extract showed a substantial reduction in the platelet count. However, the reduction was significant $(\mathrm{p}<0.05)$ when compared with the control and the 
paracetamol groups. Also, there was an appreciable reduction in platelet count when extract at $200 \mathrm{mg} / \mathrm{kg}$ and $300 \mathrm{mg} / \mathrm{kg}$ bw compared with the group that was administered with vitamin $\mathrm{C}$. The level of WBC increased significantly $(p<0.05)$ in the group administered with paracetamol only when compared with the control (Figure 7). This elevation could be attributed to hepatic injury sustained with the administration of paracetamol as was previously reported (Ogunka-Nnoka et al., 2016). The WBC level, significantly decreased $(\mathrm{p}<0.05)$ in the group that received vitamin $C$. The significant reduction $(p<0.05)$ in WBC following the administration of the aqueous leaf extract of $M$. barteri, suggests that the extract contains some bioactive agents (e.g. saponin, tannin, alkaloids and flavonoids) that could cause such destructed or imposed production of WBCs. It has also been reported that granulocytes, macrophage colony-stimulating factor, interleukins, IL-2, IL-4 and IL-5 regulate the proliferation, differentiation and maturation of committed stem cells responsible for the production of WBC (Ganong, 2001, Yakubu et al., 2003). It may be that some components of the extract reduced the production of these regulatory factors or interfered with the sensitivity of the committed stem cells (responsible for the production of WBCs). The slight increase noticed in red blood cell count after oral administration of vitamin $\mathrm{C}$ and aqueous extract of $M$. barteri suggest that the extract contain a phytochemical compound that stimulates the secretion or formation of erythropoietin in the rats. Stimulation of stem cells in the bone marrow to produce red blood cells occurs due to the action of erythropoietin which is a glycoprotein hormone (Ohisson and Aher, 2009).

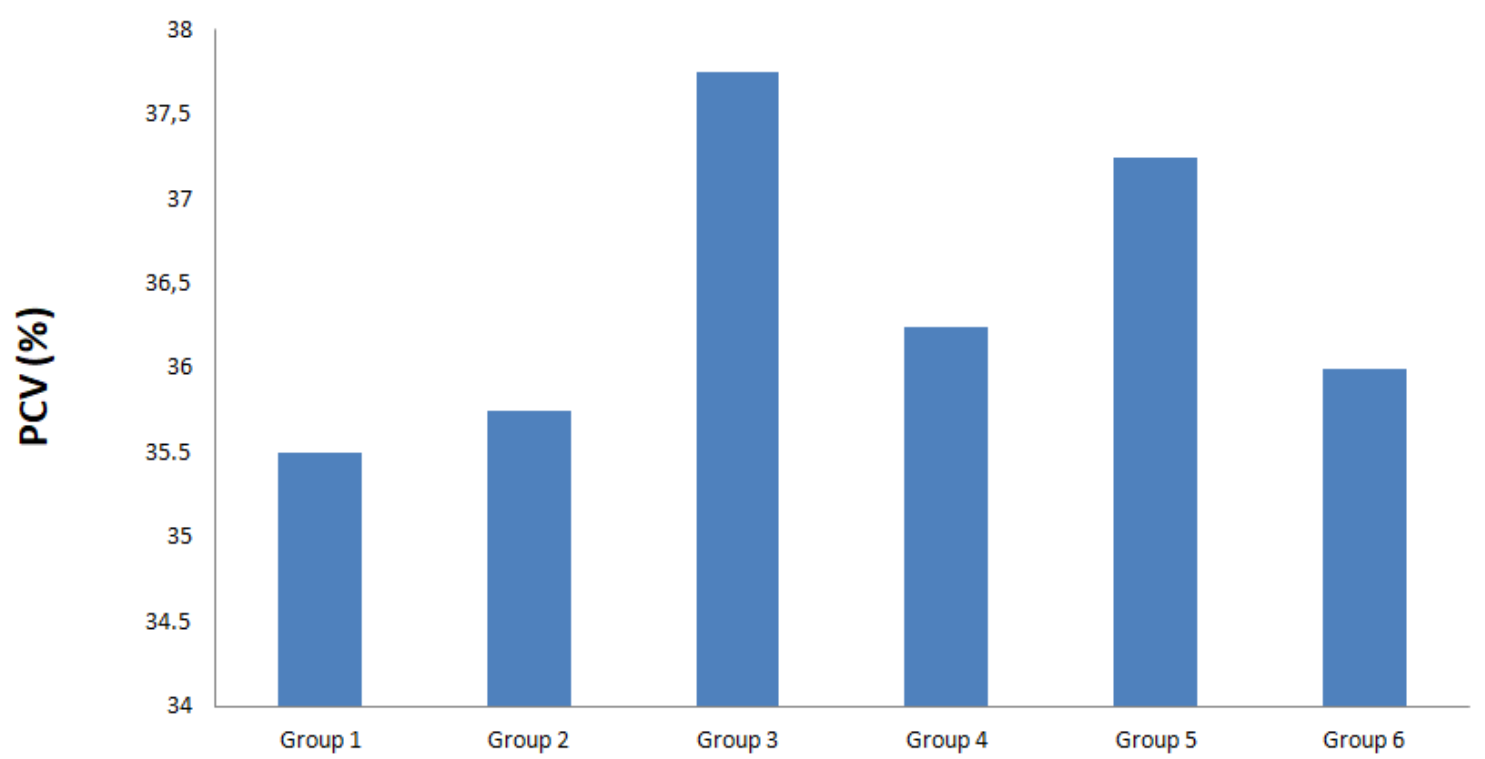

Figure 3. Effect of aqueous leaf extract of $M$. barteri on packed cell volume in paracetamol-induced wistar rats. 


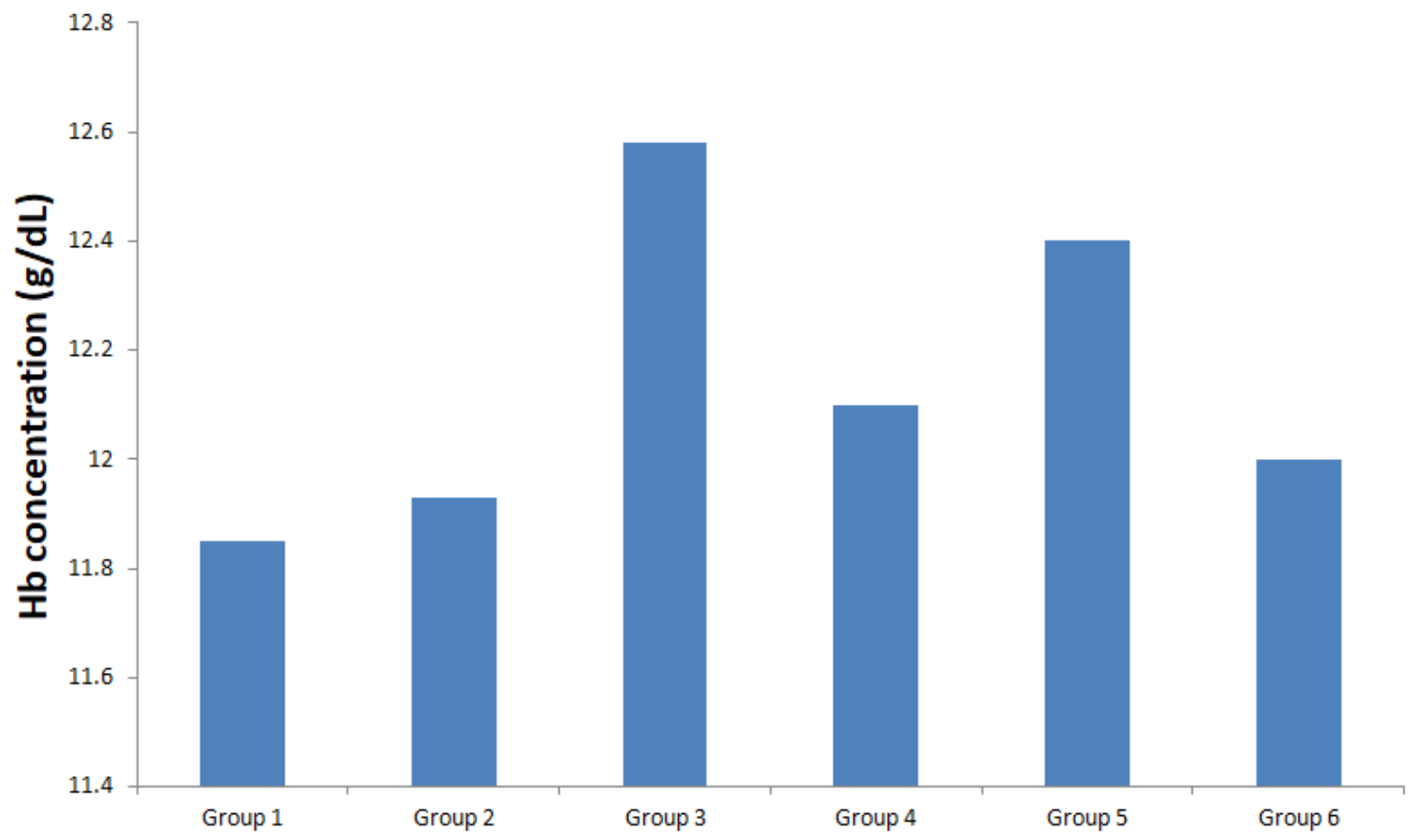

Figure 4. Effect of aqueous leaf extract of $M$. barteri on haemoglobin concentration in paracetamolinduced wistar rats.

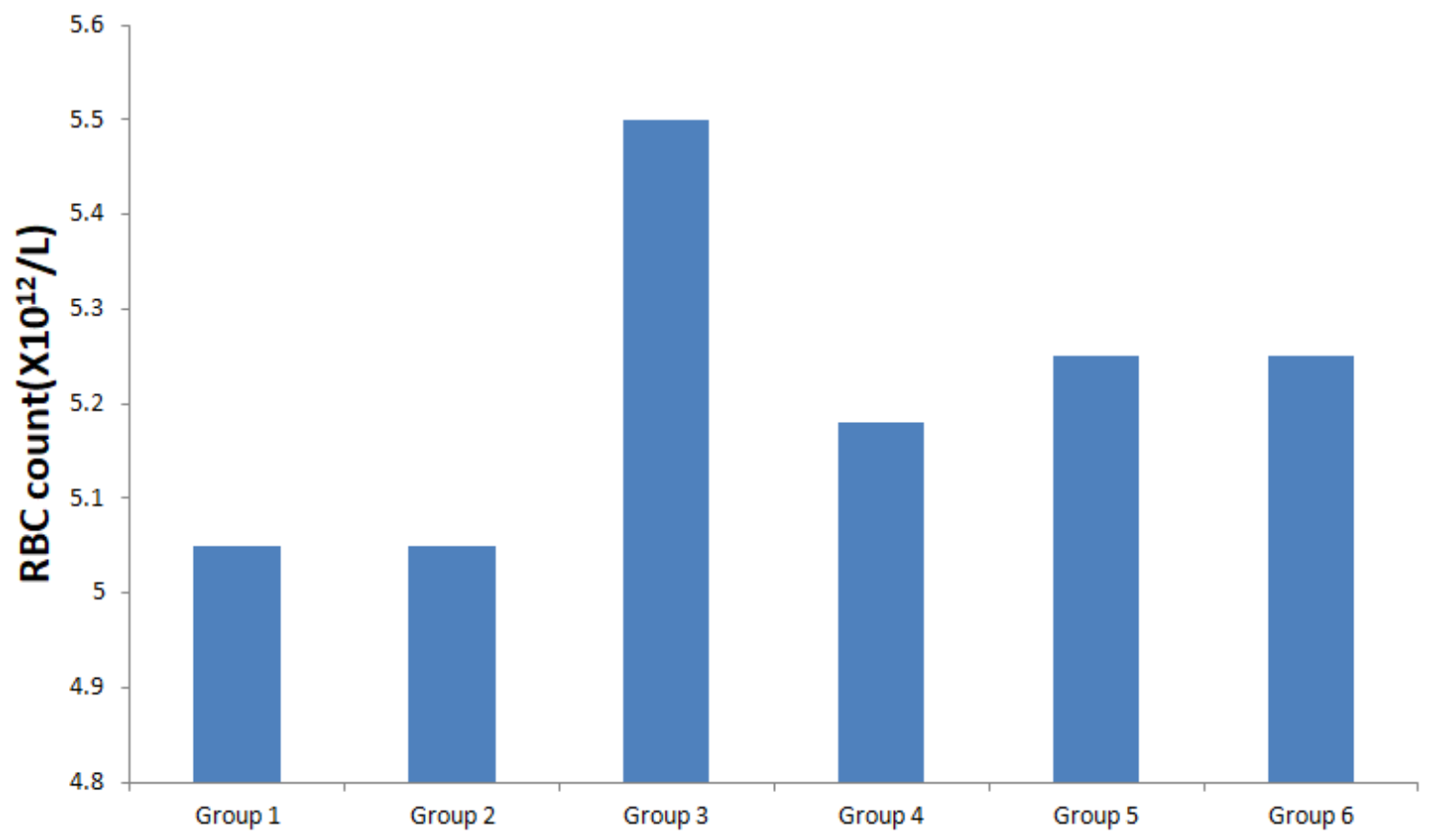

Figure 5. Effect of aqueous leaf extract of M. barteri on red blood cell count in paracetamol-induced wistar rats. 


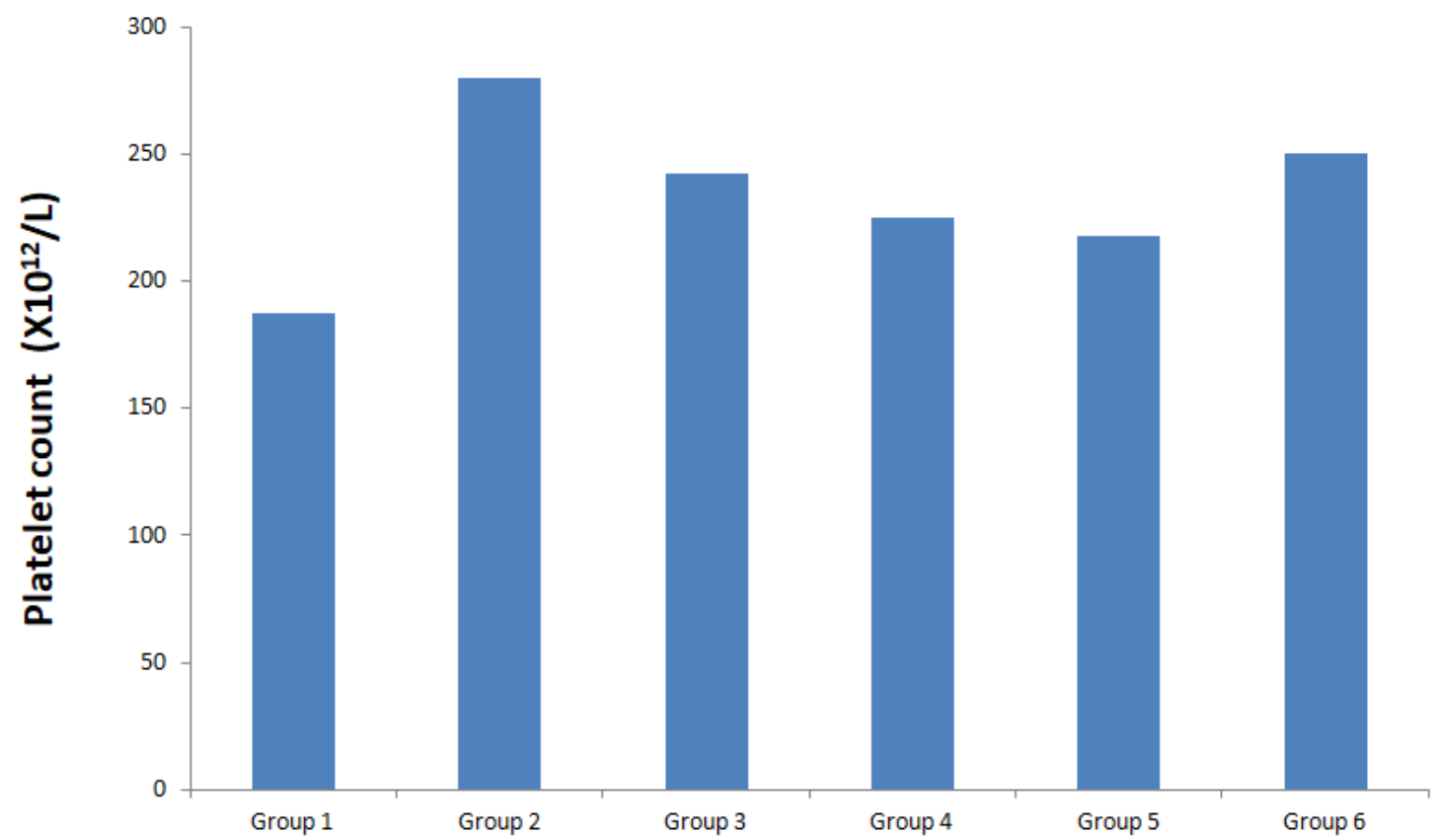

Figure 6. Effect of aqueous leaf extract of $M$. barteri on platelet count in paracetamol-induced wistar rats.

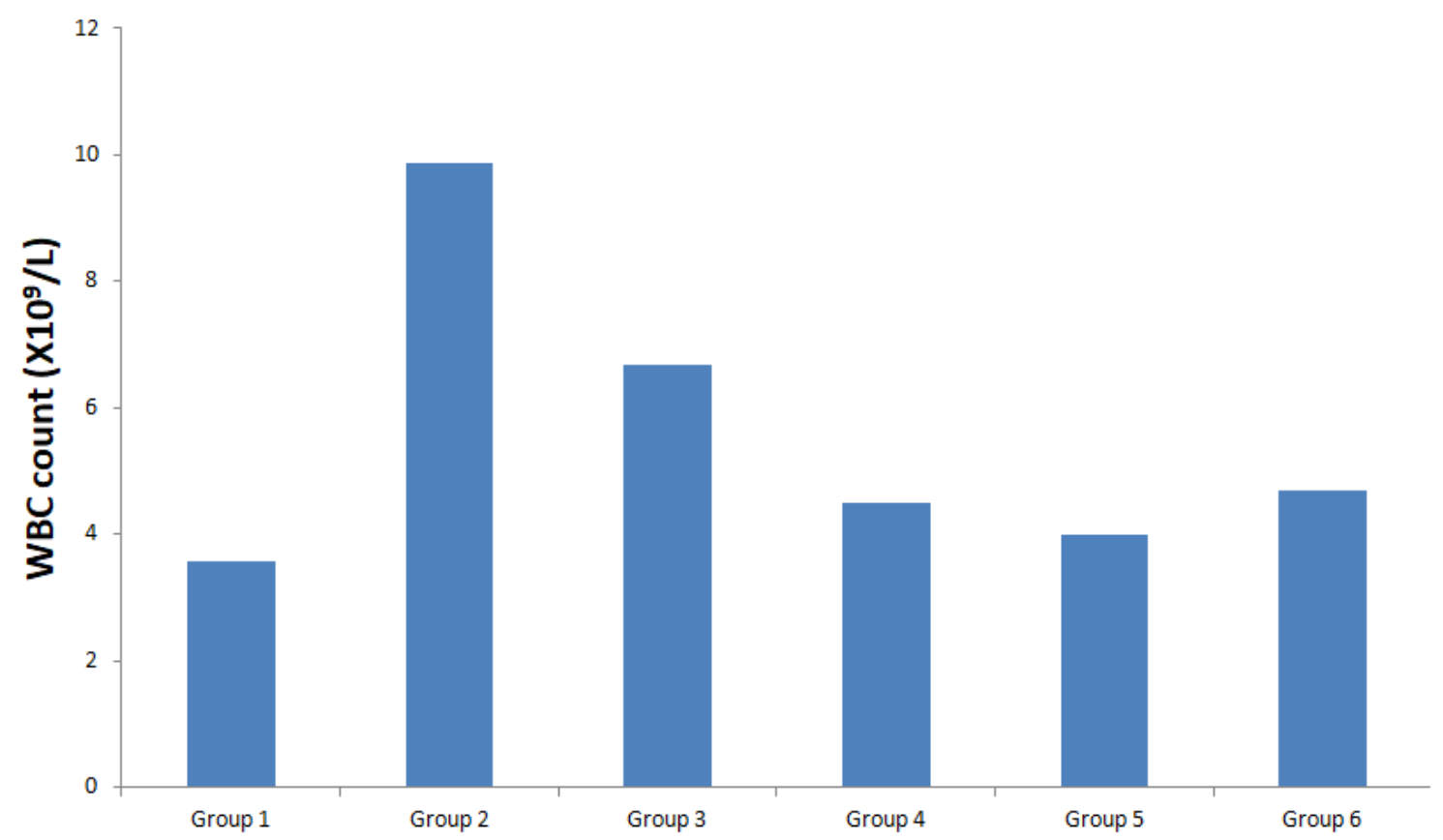

Figure 7. Effect of aqueous leaf extract of $M$. barteri on white blood cell count in paracetamolinduced wistar rats. 


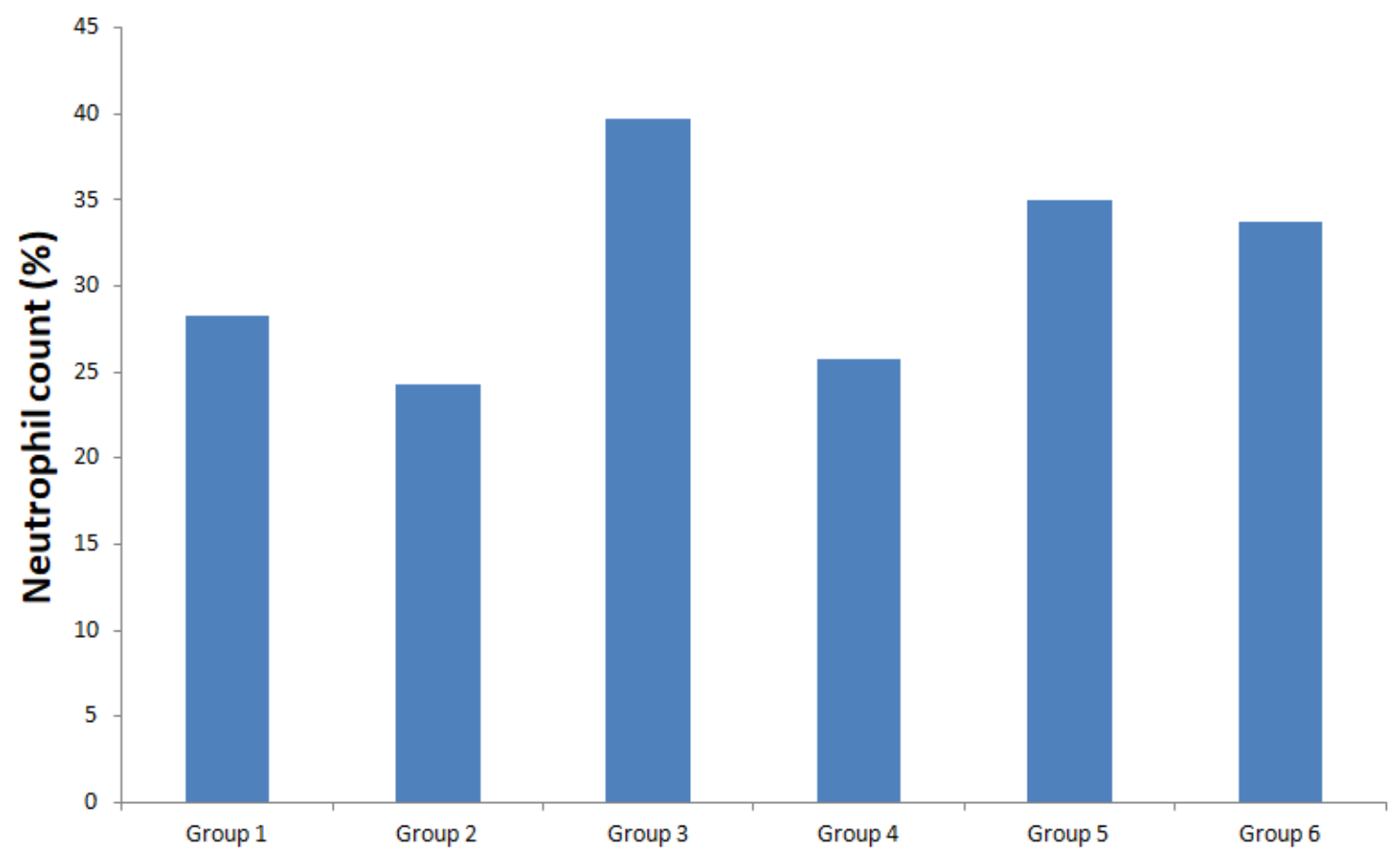

Figure 8. Effect of aqueous leaf extract of M. barteri on neutrophil count in paracetamol-induced wistar rats.

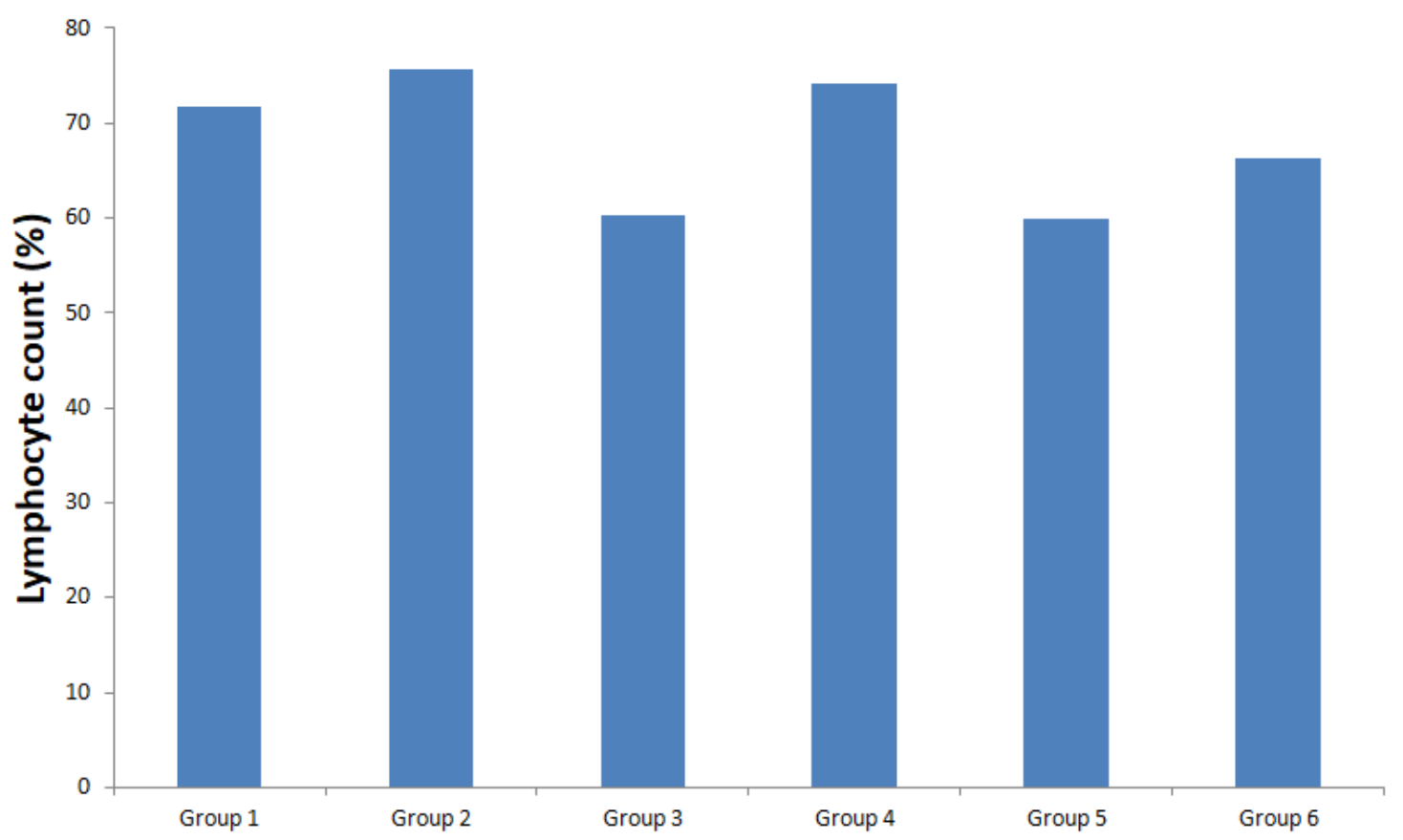

Figure 9. Effect of aqueous leaf extract of $M$. barteri on lymphocyte count in paracetamol-induced wistar rats. 
This report corroborates the report of Eseonu et al. (2010). They reported that the leaves of Peristrophe bicalculata (petz) are capable of improving red blood cell counts in experimental animals. The haematological study showed that the leaves extract of $M$. barteri demonstrated a varying degree of haematological change at the dose levels of $200 \mathrm{mg} / \mathrm{kg}$ bw and $300 \mathrm{mg} / \mathrm{kg}$ bw.

\section{Conclusion}

The study revealed that leaves of M. bartaeri are good sources of fibre, carbohydrate and protein. High levels of phytochemicals such as phenols, tannins and flavonoids were also recorded. Effect of the plant extract on haematological profile showed slight elevation in the concentration of PCV, HB, and RBC in the extract treated groups. The study suggest that leaves of $M$. bartaeri possess some blood boosting properties.

\section{Conflicts of interest}

Authors declare that they have no conflict of interests.

\section{References}

Aghababian, R. V. Essentials of emergency Medicine. Sudbury, USA: Jones \& Bartlett Publishers, 2010.

Agostoni, C.; Riva, E.; Giovannini, M. Dietary fiber in weaning foods of young children. Pediatrics, v. 96, no. 5, pt. 2, p. 1002-1005, 1995.

Akundu, M. N. An investigation of antiabortive properties of the leaves of Ocimmium grattisimum. Nsukka, Nigeria: University of Nigeria, 1984. (M. Sc. thesis).

Andzouana, M.; Mombouli, J. B. Assessment of the chemical and phytochemical constituents of the leaves of a wild vegetable: Ochthocharis dicellandroides (Gilg). Pakistan Journal of Nutrition, v. 11, no. 1, p. 94-99, 2012. https://doi.org/10.3923/pjn.2012. 94.99
Aning, K. G.; Ologun, A. G.; Onifade, A.; Alokan, J. A.; Adekola, A. I.; Aletor, V. A. Effect of replacing dried brewer's grain with sorghum rootlets on growth, nutrient utilisation and some blood constituents in the rat. Animal Feed Science and Technology, v.71, no. $1 / 2$, p. $185-190,1998$.

AOAC - Association of Official Analytical Chemists. Official methods of analysis. 16 ed. Arlington: AOAC, 1995.

Asibey-Berko, E.; Tayei, F. A. K. Proximate analysis of some underutilized Ghanaian vegetables. Ghana Journal of Science, v. 39, p.91-92, 1999. https://doi.org/10.4314/ gjs.v39i1.15862

Belewu, M.; Olatunde, O. A.; Giwa, T. A. Underutilized medicinal plants and spices: Chemical composition. Journal of African Medicine, v. 6, no. 3, p. 32-41, 2009.

Bruneton, J. Pharmacognosy, phytochemistry, medicinal plants. Hampshire: Intercept, 1995.

Cook, J. A.; VanderJagt, D. J.; Pastuszyn, A.; Mounkaila, G.; Glew, R. S.; Millson, M.; Glew, R. H. Nutrient and chemical composition of 13 wild plant foods of Niger. Journal of Food Composition and Analysis, v. 13, no. 1, p. 83-92, 2000. https://doi.org/10.1006/ jfca.1999.0843

Dalziel J. M. The useful plants of tropical West Africa. London: Crown Overseas Agents Colon, 1948.

Edeoga, H. O.; Omosun, G.; Uche, L. C. Chemical composition of Hyptis suaveolens and Ocimum gratissimum hybrids from Nigeria. Journal of Biotechnology, v. 5, no. 10 , p. $892-895,2006$.

Eseonu, K.; Imtiaz, F.; Hogben, K. A rare case of breast carcinoma presenting with paraneoplastic cerebellar degeneration. Journal of Surgical Case Reports, v. 10, no. 10, 2010. https://doi.org/10.1093/ jscr $/ 2010.10 .6$

Essiett, U. A.; Obioboho, G. E. Phytochemical, nutrients and anti-nutrients of the Ipomoea tribola, Ipomoea batatas, Ipomoea involucrata leaves. International Journal of Research, v. 1, no. 2, p. 1412-1418, 2014.

Etukudo, M. M.; Osim, S. E. Assessment of mineral, proximate and phytochemical composition of leaf, stem and root of 
Maesobotrya barteri (Baill) from secondary forest in Akwa Ibom State. International Journal of Advance Research, v. 6, no. 1, p. 500-505, 2018. https://doi.org/10.5281/ zenodo.1174561

Farquar, J. N. Plant sterols, their biological effects in human: Handbook of lipids in nutrition. Boca Raton: CRC, 1996.

Fennema, R. 0; Tannenbaum, S. R. Introduction to food chemistry. In: Fennema, S. R.; Karel, M.; Sanderson, G. W.; Tannenbaum, S. R.; Walstra, P.; Witaker, J. R. (Eds.). Food chemistry. New York, Marcel Dekker, 1996. p. 1-64.

Ganong, W. F. Review of medical physiology. 20. ed. New York: McGraw Hill, 2001.

Gupta, S. S. Prospects and perspective of natural plant products. Indian Journal of Pharmacology, v. 26, no. 1, p. 1-12, 1994.

Ilodibia, C. V.; Ugwu, R. U.; Okeke, C. U.; Ezeabara, C. A.; Okeke, N. F.; Akachukwu, E. E.; Aziagba, B. O. Determination of proximate composition of various parts of two Deacaena species. International Journal of Botany, v. 10 , no. 1 , p. $37-41,2014$. https://doi.org/ 10.3923/ijb.2014.37.41

Ishida, H.; Suzuno, H.; Sugiyama, N.; Innami, S.; Todokoro, T.; Maekawa, A. Nutritional evaluation of chemical component of leaves and stems of sweet potatoes (Ipomoea batatas Poir). Food Chemistry, v. 68, p. 359367, 2000.

Izevbigie, E. B.; Bryant, J. L.; Walker, A. A novel natural inhibitor of extracellular signalregulated kinases and human breast cancer growth. Experimental Biology and Medicine, v. 229, no. 2, p. 163-169, 2004. https://doi.org/10.1177/153537020422900 205

Kitamura, A.; Tsurugizawa, T.; Uematsu, A.; Torii, K.; Uneyama, H. New therapeutic strategy for amino acid medicine: Effects of dietary glutamate on gut and brain function. Journal of Pharmacological Sciences, v. 118, no. 2, p. 138-144, 2012. https://doi.org/10.1254/jphs.11R06FM

Mao, P.; Smerdon, M. J.; Roberts, S. A.; Wyrick, J. J. Chromosomal landscape of UV damage formation and repair at single-nucleotide resolution. Proceedings of the National
Academy of Sciences, v. 113, no. 32, p. 90579062, 2016. https://doi.org/10.1073/pnas. 1606667113

Mao, S. A.; Glorioso, J. M.; Nyberg, S. L. Liver regeneration. Translational Research, v. 163, no. 4, p. 352-362, 2016. https://doi.org/10.1016/j.trsl.2014.01.005

Mau, J. L.; Tsai, S. Y.; Tseng, Y. H.; Huang, S. J. Antioxidant properties of methanolic extracts from Ganoderma tsugae. Food Chemistry, v. 93 , no. 4 , p. 641-649, 2005. http://doi.org/ 10.1016/j.foodchem.2004.10.043

Nwauzoma, A. B.; Dawari, S. L. Studies on the phytochemical properties and proximate analysis of Piper umbellatum (Linn) from Nigeria. American Journal of Research Communication, v. 1 , no. 7 , p. 164-177, 2013.

Nwiloh, B. I.; Uwakwe, A. A.; Akaninwor, J. 0. Phytochemical screening and GC-FID analysis of ethanolic extract of root back of Salacia nitida L. Benth. Journal of Medicinal Plants Studies, v. 4, no. 6, p. 283-287, 2016.

Oboh, G. Nutritive value and haemolytic properties (in vitro) of the leaves of Vernonia amygdalina on human erythrocyte. Nutrition and Health, v. 18, no. 2, p. 151-160, 2006. https://doi.org/10.1177/026010600601800 207

Oboh, G.; Ekperigin, M. M. Nutritional evaluation of some Nigerian wild seeds. Food, v. 48, no. 2, p. 85-87, 2004. https://doi.org/10.1002/food.200200254

Ogle, B. M.; Tuyet, H. T.; Duyet, H. N.; Dung, N. N. X. Food, feed or medicine: The multiple functions of edible wild plants in Vietnam. Economic Botany, v. 57, no. 1, p. 103-117, $2003 . \quad$ https://doi.org/10.1663/00130001(2003)057[0103:FFOMTM]2.0.CO;2

Ogunka-Nnoka, C. U.; Igwe, F. U.; Orubite, K. O. Protective effect of Maeasobotrya barteri aqueous leaf extracts of Acetaminopheninduced hepatotoxicity in Wistar albino rats. European Journal of Biotechnology and Bioscience, v. 4, no. 8, p. 4-8, 2016.

Ohisson, A.; Aher, S. M. Early erythropoietin for preventing red blood cell transfusion in pre-term and/or low birth weight infants. Cochrane Database of Systematic Reviews, no. 4, p.55-64, 2014. https://doi.org/ 10.1002/14651858.CD004863.pub2 
Okwu, D. E. Phytochemicals and vitamin content of indigenous species. Pharmacology, v. 26, no. 1, p. 1-12, 2004.

Okwu, D. E.; Ekeke, O. Phytochemical screening and mineral composition of chewing sticks in South Eastern Nigeria. Global Journal of Pure and Applied Sciences, v. 9, p. 235-238, 2003.

Rao, C. V.; Newmark, H. L. Chemopreventive effect of squalene on colon cancer. Carcinogenesis, v. 19, no. 2, p. 287-290, 1998. https://doi.org/10.1093/carcin/ 19.2.287

Rumack, B.; Matthew, H. Acetaminophen poisoning and toxicity. Pediatrics, v. 55, no. 6 , p. 871-876, 1975.

Sahu, N. P.; Mahato, S. B. Anti-inflammatory triterpene saponins of Pithecelobium dulce: Charaterizatiobn of an echinocystic acid bisdesmoside. Phytochemistry, v. 37, no. 5, p. 1425-1427, $1994 . \quad$ https://doi.org/ 10.1016/s0031-9422(00)90425-4

Saura-Calixto, F.; Cañellas, J.; Soler, L. Dietary fibre and components of the nitrogen free extract of almond kernels. Journal of the Science of Food and Agriculture, v. 34, no. 12 , p. 1419-1422, 1983. https://doi.org/ $10.1002 /$ jsfa.2740341216
Sofowore. L.A. Medicinal plants and traditional medicine in Africa. Ibadan: Spectrum Books, 1993.

Sparg, S. G.; Light, M. E.; Van-Staden, J. Biological activities and distribution of plant saponins. Journal of Ethnopharmacology, v. 94, no. $2 / 3, \quad$ p. $219-243,2004$. https://doi.org/10.1016/j.jep.2004.05.016

Vanderjagt, D. J.; Freiberger, C.; Vu, H. T.; Mounkaila, G.; Glew, R. S.; Glew, R. H. The trypsin inhibitor content of 61 wild edible plant foods of Niger. Plant Foods for Human Nutrition, v. 55, no. 4, p. 335-346, 2000. https://doi.org/10.1023/A:1008136100545

Yakubu, M. T.; Bilbis, L. S.; Lawal, M.; Akanji, M. A. Evaluation of selected parameters of rat liver and kidney function following repeated administration of yohimbine. Biochemistry, v. 15 , no. 2 , p. $50-56,2003$. 